\title{
Suicidal Major Depression in a Healthcare Worker Associated with the COVID-19 Pandemic: A Case Report
}

\author{
Bir Sağlık Çalışanında COVID-19 Pandemisi ile İlişkili İntihar Düşüncesinin Eşlik Ettiği \\ Majör Depresyon: Olgu Sunumu
}

\author{
Gizem Nur PALA \\ (D) 0000-0003-2381-2311 \\ Buket CINEMRE \\ (D) 0000-0001-6480-1454 \\ Ali ERDOĞAN \\ (D) 0000-0003-0329-6778
}

Akdeniz University Faculty of Medicine Department of Psychiatry, Antalya, Turkey

\section{Corresponding Author \\ Sorumlu Yazar \\ Ali ERDOĞAN \\ erdoganali006@hotmail.com}

Received / Geliş Tarihi : 11.11.2020 Accepted / Kabul Tarihi : 19.01.2021 Available Online /

Çevrimiçi Yayın Tarihi : 07.02.2021

\begin{abstract}
Novel coronavirus disease (COVID-19) pandemic has been affecting the whole world since December 2019. During the pandemic, healthcare professionals are at the forefront of the fight against COVID-19, and many healthcare workers died during this fight. Healthcare workers, who are at the forefront of the pandemic, are under intense mental and physical stress along this period. This disease makes increase psychiatric symptoms for general population and especially in health professionals at pandemic conditions. In particular, the symptoms of burnout, depression, and anxiety have rised significantly. With this case report, we present a physician who had symptoms that started during the COVID-19 pandemic, had depression accompanied by suicidal thoughts, and went into complete remission with electroconvulsive therapy. The mental health effects of healthcare workers who have had COVID-19 are discussed within the frame of this case report.
\end{abstract}

Keywords: Heathcare workers; COVID-19; pandemic; depression; suicidal thoughts.

\section{ÖZ}

Yeni koronavirüs hastalığı (COVID-19) pandemisi Aralık 2019'dan bu yana tüm dünyayı etkilemektedir. Pandemi sürecinde sağlık çalışanları COVID-19 ile mücadelede en önde savaşmaktadır ve birçok sağlık çalışanı bu mücadele sırasında hayatını kaybetmiştir. Pandeminin ön saflarında yer alan sağlık çalışanları bu dönemde yoğun ruhsal ve fiziksel stres altındadır. Pandemi dönemlerinde genel popülasyonda ve özellikle sağlık çalışanlarında psikiyatrik belirtiler ve hastalıklar artmaktadır. Özellikle tükenmişlik, depresyon ve anksiyete belirtileri önemli ölçüde artar. $\mathrm{Bu}$ olgu sunumunda, COVID-19 pandemisi sırasında semptomları başlayan, intihar düşüncelerinin eşlik ettiği depresyonu olan ve elektrokonvülsif terapi ile tam remisyona giren bir hekim sunulmaktadır. COVID-19 pandemisinin sağlık çalışanlarının ruh sağlığı üzerindeki etkileri bu olgu sunumu çerçevesinde tartışılmaktadır. Anahtar kelimeler: Sağlık çalışanları; COVID-19; pandemi; depresyon; intihar düşüncesi.

\section{INTRODUCTION}

In December 2019, a severe acute respiratory syndrome (SARS) outbreak caused by a new coronavirus started in Wuhan, China. On March 11, 2020, the World Health Organization declared coronavirus disease 2019 (COVID-19) as a pandemic (1). Healthcare workers, who had been on the front line of the fight against the pandemic since the first day, are exposed to intense physical and mental stress, mainly due to heavy workload and the fear of contamination. Experiences and observations from previous pandemics show that healthcare workers are more susceptible to psychiatric disorders in such situations (2). Recent studies published shortly after the onset of the COVID-19 pandemic similarly reveal that healthcare workers' mental health is negatively affected (3). The risk of suicide probability increases with the long-term effects of the pandemic on the general population. Especially societies with significant social and economic losses are considered more risky in this regard. That 
situation, which is defined as "suicide storm", which may increase after the pandemic, causes serious concerns (4). Throughout the pandemic period, an increase in psychiatric diseases and suicidal behavior can be observed. Healthcare workers and the elderly, who are among the particularly vulnerable groups, are above all at risk for suicide (5). Researches are commonly screen studies of mental symptoms, and we do not yet have definitive data on the prevalence of psychiatric morbidity associated with the pandemic. Assuming that the epidemic continues at the same pace, these data will be completed is also uncertain. In this case report, we present a case of suicidal depression in a physician whose symptoms started soon after the pandemic outbreak and who recovered after electroconvulsive therapy (ECT) and aim to discuss the impact of the COVID-19 pandemic on the mental health of health workers.

\section{CASE REPORT}

A 62-year-old male patient works as an anesthesiologist at a private hospital. The patient admitted to the psychiatric outpatient clinic with suicidal thoughts, anhedonia, fear of contracting COVID-19, and fear of transmitting COVID19 to other people. The patient had no previous psychiatric illness history until three months ago, just when the COVID-19 was officially announced in Turkey. After putting a patient with an upper respiratory tract infection to sleep, he started to experience similar symptoms, which led him to worry that he was infected with the COVID-19. Since an antiviral treatment for his nasopharyngitis did not improve his symptoms, the patient underwent a negative polymerase chain reaction (PCR) test for COVID-19. However, he was still preoccupied with worries about being infected, which then turned to a growing fear of death. Fearing that he might infect other people, he isolated himself from everyone, including his wife. Simultaneously, the patient started to feel depressed and was even intolerant of his beloved granddaughter's presence. Things he used to enjoy were a source of boredom partly because he was easily distracted from what he was doing. Reading news and articles about COVID-19 was almost his only daily activity. He did not eat much, but this was mostly due to abdominal pain and increased intestinal motility, especially after eating. However, endoscopic and colonoscopic evaluations revealed no pathology. He had difficulty falling asleep; thus, he started taking alprazolam $0.5 \mathrm{mg} /$ day, which was ineffective for his abdominal pain kept him awake all night. The patient began to feel useless and thought that it would be better to die. Occasionally, these thoughts would intensify to such an extent that he made suicide plans. There was no suicide attempt. The patient had a plan to suicide by taking anesthetic agents. The patient was born in a small Aegean town to a lowincome family with three children. During times of childhood, he used to take on responsibilities incomparable to his young age. His academic life has always been a success story, and unlike his other two siblings, he left his hometown to continue his university education. His mother was a disciplined and overprotective person who kept the patient and his siblings under control, which was to be passed later to the patient as he grew old. It can be said that the over controlling attitude of the mother leads to a perfectionist personality in the patient. Perfectionism may contribute to the development of depressive symptoms and suicidal ideation by interacting with the stress of success. He described his siblings as always depressive personalities, and his sister also had COVID-19 anxiety similar to the patient.

He had a meticulous, controlling but also cheerful and extrovert premorbid personality. He was loved and trusted by his colleagues and thought himself as a good parent to his children. The patient, who had hypertension and subclinical hyperthyroidism, had no history of addiction. At first glance, his overuse of protective equipment against COVID-19 was notable. He felt worthless and suicidal and was excessively preoccupied with COVID-19 transmission. In the mental state examination, his self-care was bad, and he had a depressed mood. His thought structure was normal and his thought content had intense suicidal thoughts. He did not have any psychotic symptoms. Affect was depressed. He had mild psychomotor retardation. The patient was diagnosed with major depression according to DSM-5 diagnostic criteria. Detailed blood tests and brain imaging also revealed no pathology. His Hamilton depression (HAM-D) rating score was 41 points, whereas he got 12 points from the Beck scale for suicide ideation (BSSI). Since he was severely depressed with intense suicidal thoughts, the patient was hospitalized. The patient had a serious suicide risk and therefore ECT was chosen primarily. The patient was discharged on the $4^{\text {th }}$ day of hospitalization at his own request and the request of his family. He continued to receive ECT. He received ten sessions of ECT, at the end of which he was in complete remission. Every other day, 3 times a week and bilateral ECT protocol was applied. He was put on a daily dose of $100 \mathrm{mg}$ oral sertraline. The patient was followed up in the outpatient clinic monthly after discharge. At the $6^{\text {th }}$ month follow-up, the patient's HAM-D score was 2 and BSSI score was 0 . The patient had no complaints.

\section{DISCUSSION}

In this case report, we presented the case of a healthcare worker who suffered from a severe suicidal depressive episode, which we thought to be precipitated by the COVID 19 pandemic. After a suspicious contact in the first days of the COVID-19 pandemic, fear of being infected turned to a severe form of health anxiety in the patient who had no previous psychiatric history, with ambiguous somatic complaints such as abdominal pain. Soon, a full-blown depressive episode manifested itself and led the patient to seek for professional help. Although it is impossible to establish a definite relationship, the triggering factor here seems to be the patient's fear of being infected with the coronavirus. Indeed, a sudden and life-threatening epidemic can place enormous strain on healthcare professionals because of factors such as increased workload, fear of contagion, and the need to make ethically difficult decisions $(6,7)$. It is reported that during the COVID-19 pandemic, most healthcare professional experienced mild symptoms of both depression and anxiety and that the prevalence of moderate-to-severe symptoms was low (8). However, in our case, the clinical picture went far beyond mild symptoms, and ended up in a suicidal depression.

Physicians have a higher risk of suicide compared to the normal population. Factors such as psychological pressure and an intense fear of death during the epidemic might have increased the risk (9). The case of Dr. Lorna Breen 
was both a painful and alarming example in this regard. She was the medical director of the emergency department in a community hospital in New York, where she contracted coronavirus from one of her patients and ended her life in April 2020 (10). Our patient and Dr. Breen show us the extent of psychiatric risk the healthcare workers might be facing during the COVID-19 pandemic, which is still full speed.

Our patient had several risk factors that might have predisposed him to depression. One such factor is his having comorbid physical illnesses, namely essential hypertension, and subclinical hyperthyroidism. Indeed comorbid physical illness was one of the reported risk factors for psychiatric morbidity among healthcare workers during the COVID-19 outbreak (11). High levels of social media exposure with pandemic content are also reported to be positively associated with mental health problems during the pandemic. In this regard, the patient's extensive internet use to get information about COVID-19 might have been a permanent source of anxiety and provoked his depression (12).

The case we presented here is a severe depression that psychiatric professionals may often encounter in their practice, and also full remission of symptoms is not exceptional, given the high efficiency of ECT. However, almost all experts agree that the COVID-19 pandemic will not end any time soon. This means that healthcare workers will continue to be in the field and will be even more mentally vulnerable (13).

\section{CONCLUSION}

This is a warning case which shows the extent of psychiatric morbidity in healthcare workers associated with the pandemic. Questioning suicidal thoughts in evaluating the mental symptoms of healthcare workers who have taken an active role in the pandemic period can be life-saving. Thus healthcare professionals should be closely monitored in terms of early diagnosis and treatment of psychiatric disorders, and protective measures should be taken. Studies with large samples evaluating the suicide risk of healthcare workers are needed during the pandemic period.

Informed Consent: Written informed consent was obtained from the patient for publication.

Conflict of Interest: None declared by the authors.

Financial Disclosure: None declared by the authors.

Acknowledgements: None declared by the authors.

Author Contributions: Idea/Concept: GNP, BC, AE; Design: GNP, BC, AE; Data Collection/Processing: GNP, BC, AE; Analysis/Interpretation: GNP, BC, AE; Literature Review: GNP, BC, AE; Drafting/Writing: GNP, BC, AE; Critical Review: GNP, BC, AE.

\section{REFERENCES}

1. Sohrabi C, Alsafi Z, O'Neill N, Khan M, Kerwan A, Al-Jabir A, et al. World Health Organization declares global emergency: A review of the 2019 novel coronavirus (COVID-19). Int J Surg. 2020;76:71-6. Erratum in: Int J Surg. 2020;77:217.

2. Verma S, Mythily S, Chan YH, Deslypere JP, Teo EK, Chong SA. Post-SARS psychological morbidity and stigma among general practitioners and traditional Chinese medicine practitioners in Singapore. Ann Acad Med Singap. 2004;33(6):743-8.

3. Lai J, Ma S, Wang Y, Cai Z, Hu J, Wei N, et al. Factors associated with mental health outcomes among health care workers exposed to coronavirus disease 2019. JAMA Netw Open. 2020;3(3):e203976.

4. Hocaoğlu Ç, Erdoğan A. COVID-19 and suicide. In: Coşar B, editor. Psychiatry and COVID-19. $1^{\text {st }}$ ed. Ankara: Türkiye Klinikleri; 2020. p.35-42.

5. Devitt P. Can we expect an increased suicide rate due to Covid-19? Ir J Psychol Med. 2020;37(4):264-8.

6. Liu X, Kakade M, Fuller CJ, Fan B, Fang Y, Kong J, et al. Depression after exposure to stressful events: lessons learned from the severe acute respiratory syndrome epidemic. Compr Psychiatry. 2012;53(1):15-23.

7. Cheung T, Fong TKH, Bressington D. COVID-19 under the SARS Cloud: Mental Health Nursing during the Pandemic in Hong Kong. J Psychiatr Ment Health Nurs. 2020;[Epub ahead of print]. doi: 10.1111/jpm.12639.

8. Pappa S, Ntella V, Giannakas T, Giannakoulis VG, Papoutsi E, Katsaounou P. Prevalence of depression, anxiety, and insomnia among healthcare workers during the COVID-19 pandemic: A systematic review and meta-analysis. Brain Behav Immun. 2020;88:9017.

9. Dutheil F, Aubert C, Pereira B, Dambrun M, Moustafa F, Mermillod M, et al. Suicide among physicians and health-care workers: A systematic review and metaanalysis. PLoS One. 2019;14(12):e0226361.

10. Zangeneh M. Heroes should not die by suicide: The tragic life of Dr. Lorna Breen. INYI Journal. 2020;10(1-2):29.

11. Zhang WR, Wang K, Yin L, Zhao WF, Xue Q, Peng $\mathrm{M}$, et al. Mental health and psychosocial problems of medical health workers during the COVID-19 epidemic in China. Psychother Psychosom. 2020;89(4):242-50.

12. Gao J, Zheng P, Jia Y, Chen H, Mao Y, Chen S, et al. Mental health problems and social media exposure during COVID-19 outbreak. PLoS One. 2020;15(4):e0231924.

13. Lu W, Wang H, Lin Y, Li L. Psychological status of medical workforce during the COVID-19 pandemic: A cross-sectional study. Psychiatry Res. 2020;288:112936. 